EETP Vol. 15, 2020, №. 3(57)

ISSN $1896-2327$ / e-ISSN 2353-7787

DOI: $10.35765 /$ eetp.2020.1557.05

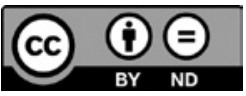

Submitted: 11.05 .2020

Accepted: 22.07 .2020

Suggested citation: Żmijewska E. (2020). Including pupils who have experienced migration during the COVID-19 pandemic, "Elementary Education in Theory and Practice," vol. 15, no. 3(57), pp. 67-79. DOI: 10.35765/eetp.2020.1557.05

\title{
Including Pupils Who Have Experienced Migration During the COVID-19 Pandemic
}

\author{
Inkluzja uczniów z doświadczeniem migracji \\ w czasach pandemii Covid-19
}

\section{KEYWORDS}

COVID-19

pandemic, inclusive education, online learning, special educational needs, students who have experienced migration

\section{ABSTRACT}

The COVID-19 pandemic, which has rapidly spread globally since the beginning of 2020 , poses a number of challenges for the educational system. Educational institutions have been closed, and teaching/learning is now being done online. The coexistence of these two events, namely, online learning and pupils who have experienced migration in Polish schools, serve as the starting point for my study. The aim of the study is to obtain feedback from early years teachers on the possible inclusion of pupils who have experienced migration in the online learning process and to identify the self-reported priorities for teachers' tasks during the pandemic and the actual ways in which teachers offer opportunities for inclusion to the students involved in the study. An online survey was used in the study as the research method.

The article is composed of two parts: the theoretical part, which describes the educational situation of the students who have experienced migration and selected issues associated with inclusive education, and the empirical part, which provides analysis and interpretation of the data obtained in the study. The study offers conclusions on the hierarchy of priorities for teachers' tasks (the majority of the respondents mentioned "providing emotional support to pupils") 
and the particulars of including students who have experienced migration into the online learning process (a majority of the teachers reported the need for more personalized teaching and close cooperation with pupils' families).

Given the number of respondents (83 teachers) and the survey methodology, the results should be treated with caution. That said, they are worth sharing as an inspiration for early years teachers to seek and reflect on their own solutions to the problem.

\section{SŁOWA KLUCZE ABSTRAKT}

pandemia Pandemia koronawirusa Covid-19, która od pierwszych miesięcy Covid-19, edukacja 2020 roku błyskawicznie opanowała prawie cały świat, postawiła inkluzyjna, niezwykle trudne zadania przed edukacją. Placówki oświatowe zostanauka online, ły zamknięte, a procesy nauczania/uczenia się przeniesiono do sieci. specjalne potrzeby Współistnienie dwu zjawisk - obecności w polskiej szkole dzieci z doedukacyjne, uczeń z doświadczeniem świadczeniem migracji oraz kształcenia w trybie online - stanowiło punkt wyjścia do przeprowadzonego przeze mnie badania. Jego celem migracji było poznanie opinii nauczycieli edukacji wczesnoszkolnej na temat możliwości włączania uczniów z doświadczeniem migracji w proces nauki online, ustalenie deklarowanych priorytetów zadań nauczycieli w czasie pandemii oraz faktycznie realizowanych sposobów inkluzji interesujących mnie uczniów. Zastosowaną w badaniu techniką była ankieta internetowa.

Artykuł składa się z części teoretycznej, w której przedstawiona została sytuacja edukacyjna dzieci z doświadczeniem migracji oraz wybrane zagadnienia z zakresu edukacji inkluzyjnej, a także części badawczej, gdzie dokonano analizy i interpretacji uzyskanego materiału empirycznego. Wnioski odnoszą się do hierarchii priorytetów zadań nauczycieli (tu zdecydowana większość badanych wskazała „zapewnienie uczniom wsparcia emocjonalnego") oraz specyfiki włączania uczniów z doświadczeniem migracji w naukę online (tu nauczyciele deklarowali przede wszystkim daleko idącą indywidualizację oraz konieczność ścisłej współpracy z rodziną dziecka).

Liczebność badanej grupy (83 nauczycieli) oraz zastosowana technika ankiety nakazują ostrożność w interpretowaniu uzyskanych wyników. Niemniej jednak sądzę, że warto je upowszechnić, chociażby w celu inspirowania nauczycieli klas I-III do samodzielnej refleksji oraz szukania własnych rozwiązań. 


\section{Introduction}

Education is one area of social life that has suffered a heavy blow from the consequences of the Covid-19 pandemic. Already struggling with what one might call everyday problems, it was additionally faced with a difficult or even daunting task: to move online as quickly as possible. As soon as possible does not usually mean as well as possible, but we took a stab at it. It is not my intention to describe the current functioning of the school system as a whole, with all its challenges and problems. I would like to focus on one area instead.

At all levels of education, there are students with what is defined as special educational needs. This group also includes children who have experienced migration, who are the subject of inclusion policies in the Polish educational system. Being aware of the double challenge faced by teachers who have such students in their classrooms (the inclusion of students who have experienced migration in online teaching), I decided to carry out a survey among them. This article analyzes the results of that survey.

\section{The Special Educational Needs of a Student Who Has Experienced Migration}

The term "special educational needs" was introduced by Mary Warnock in the Warnock Report: Special Educational Needs, published in 1978 in London by Her Majesty's Stationery Office. The author proposed moving away from the medical categorization of students and their diagnosed deficits to a more functional language with social understanding of their needs. The new legal acts have extended the scope of the term to also cover needs of students resulting from the problems of modern society, e.g. migration, crisis situations, belonging to a national minority, or an ethnic group (see Wiszejko-Wierzbicka 2012: 71-86).

Such an understanding of the situation of students with the experience of migration was also reflected in the provisions of the Polish educational law. Paragraph 2 of the Regulation of the Minister of National Education of August 9, 2017 on the rules for the organization and provision of psychological and pedagogical assistance in public kindergartens, schools, and institutions stipulates that

1. Psychological and pedagogical assistance provided to a student in a kindergarten, school, or educational facility consists of identifying and satisfying the individual development and educational needs of the student as well as identifying the individual psychophysical abilities of the student and the environmental factors influencing their functioning in the kindergarten, school, or educational facility in order to support the developmental potential of the student and to create conditions for their 
active and full participation in the life of the kindergarten, school, or educational facility and in the social environment.

2. Psychological and pedagogical assistance in a kindergarten, school, or educational facility is to be provided to students with:

1) disability;

2) social maladjustment issues;

3) risk of social maladjustment;

4) behavioral or emotional disorders;

5) special giftedness;

6) specific learning difficulties;

7) competence deficits and language skill disorders;

8) a chronic disease;

9) crisis or traumatic situations;

10) educational failures;

11) negligence related to the living situation of the student and their family, freetime activities, and social interactions; or

12) adaptation difficulties related to cultural differences or a change in educational setting, also connected with prior education abroad (Regulation of the Minister of National Education of August 9, 2017).

When looking for information describing the schooling of a child who has experienced migration, we must not ignore the provisions of the Green Paper of the European Commission. The authors of this recommendation clearly articulate that the educational situation of migrant students is influenced by the fact that they and their families experience a loss of value and the knowledge which they had acquired, especially in their mother tongue, but also the knowledge of the functioning of institutions and the specific features of educational systems. They also make a case for the key role of language and recall that a good knowledge of the language of instruction is a basic condition for success in school. This can pose a problem, even for migrant children born in their host country if the language used at school cannot also be practiced at home. Language can also act as a barrier between migrant families and school, making it difficult for parents to help their children. (European Commission 2008). Only on the grounds quoted above is it possible to compile a register of the challenges faced by a teacher who models an educational dialogue with a culturally diverse class.

The rapidly spreading pandemic of the Covid-19 virus caused the Minister of National Education to issue the Ordinance on the Temporary Limitation of the Functioning of Educational System Facilities on March 11, 2020 in Connection with the Prevention, Counteraction, and Combating of COVID-19 (Regulation of March 11,2020). On the basis of this document and subsequent regulations and 
recommendations announced as the pandemic has progressed, ${ }^{1}$ the teaching/learning process has been transferred online. Apart from the obvious problems-mainly from the lack of preparation of both teachers and students for distance learning or even the insufficient numbers and quality of computer equipment—students with special educational needs met with formidable challenges. It would seem that the Ministry did not forget about them in the guidelines, though we can only find a handful of fairly general recommendations posted on the Ministry of National Education website, in one of the tabs (see https://www.gov.pl/web/edukacja/wsparcie-uczniow-ze-specjalnymi-potrzebami-edukacyjnymi). Most importantly, for the research problem of interest to us, the understanding of special educational needs was limited only to students with various types of disabilities and deficits, not students who have experienced migration.

\section{Research methods}

With the everyday practice of remotely teaching students of grades $1-3$ and being aware of the difficulties that children with migration experience have at this stage of learning (based on insight from research and school practice so far), I conducted a questionnaire using a survey technique among early school education practitioners.

The subject of my research was their opinions on the most important tasks of the early childhood education teacher at the moment and in the process of including students who have experienced migration in distance learning. The research problems were formulated as two questions:

1. What are the most important tasks of an early childhood education teacher, in your opinion?

2. What ways, if any, are there of including students who have experienced migration in the distance learning process?

The technique for collecting empirical material was chosen due to the current situation: I used an online questionnaire, which contained six questions about the subject of the study (including four open-ended questions, one semi-open question, and one closed question) and three personal identification questions (gender, work experience, and workplace). The survey was available from April 14 to April 30, 2020, i.e., after the respondents had already had a month of experience in remote education.

1 Cf. Regulation of the Minister of National Education of March 20, 2020 amending the Regulation on the Temporary Limitation of the Functioning of Education System Facilities in Connection with the Prevention, Counteraction, and Combating of COVID-19; Regulation of the Minister of National Education of March 20, 2020 on Special Solutions in the Period of Temporary Limitation of the Functioning of Education System Facilities in Connection with the Prevention, Counteraction and Combating of COVID-19; https://www.gov.pl/web/edukacja/ksztalcenie-na-odleglosc-nowe-regulacje-prawne. 
The questionnaire was filled out by 83 teachers of grades $1-3$. The demographic information about the study group is presented in Figures 1-3.

Figure 1. Gender of the Teachers Surveyed

\section{Teachers' gender}

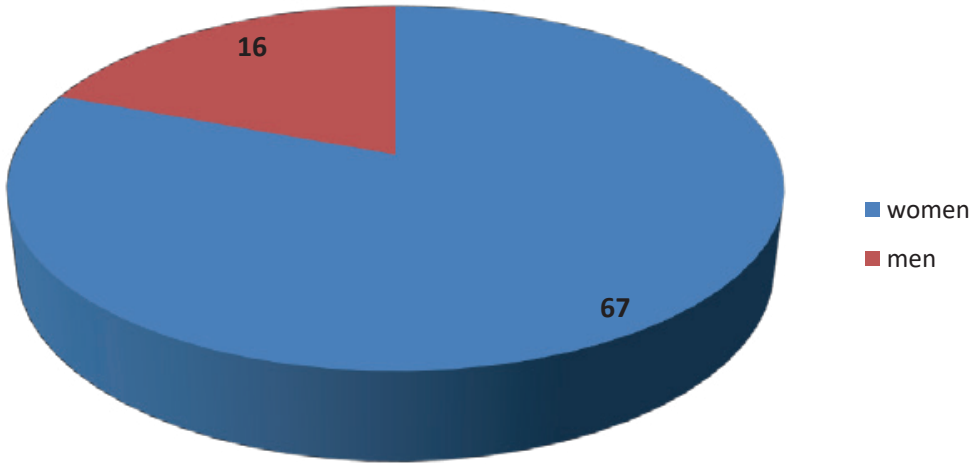

Figure 2. Work Experience as an Early Childhood Education Practitioner of the Teachers Surveyed

\section{Work experience}

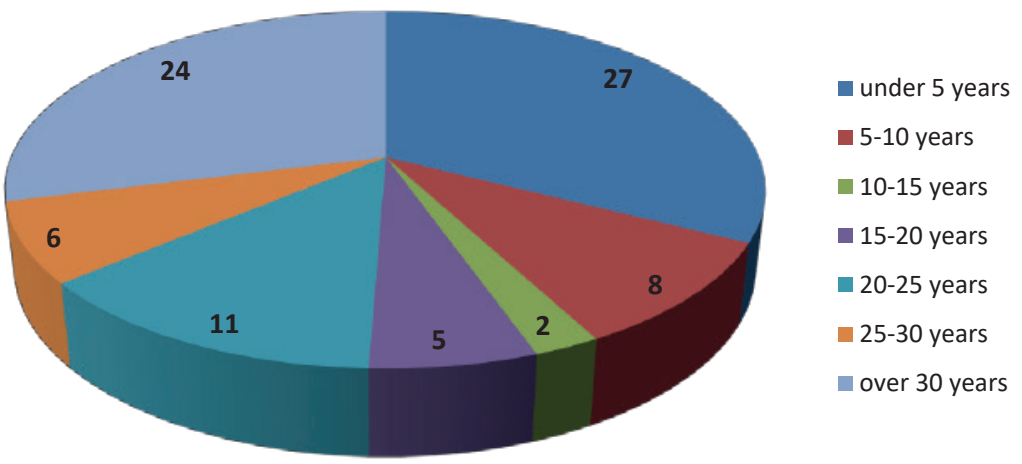


Figure 3. Workplace of the Teachers Surveyed

\section{Workplace}

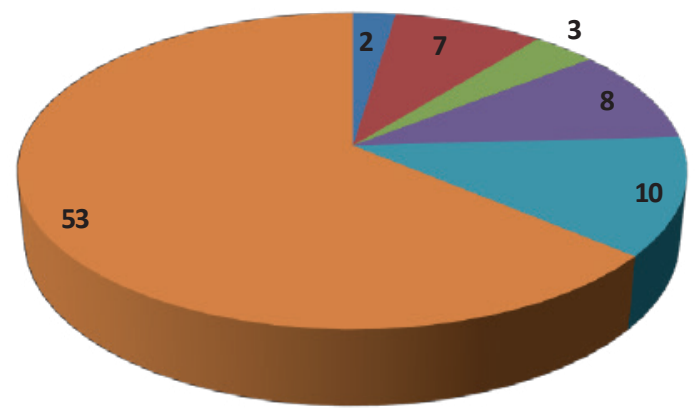

rural area

- town with up to 10,000

inhabitants

town with up to 50,000

inhabitants

city with up to 100,000

inhabitants

city with up to 500,000

inhabitants

city with over 500,000

inhabitants

The analysis revealed that these data did not constitute a discriminating variable; therefore, the interpretation did not take into account any regularities that could result from them.

\section{The Most Important Tasks of a Teacher During a Pandemic, According to Early Childhood Education Practitioners}

In the first question of the main part of the survey, I asked the teachers to reflect on the importance of teachers' tasks. I wanted to learn how they perceive these tasks in this unusual situation. The respondents were asked to choose the three most important—in their opinion — tasks from a list. They also had the opportunity to add their own suggestions to the list. I present their choices in Figure 4. 
Figure 4. Tasks of Early Childhood Education Teachers During a Pandemic, According to the Respondents

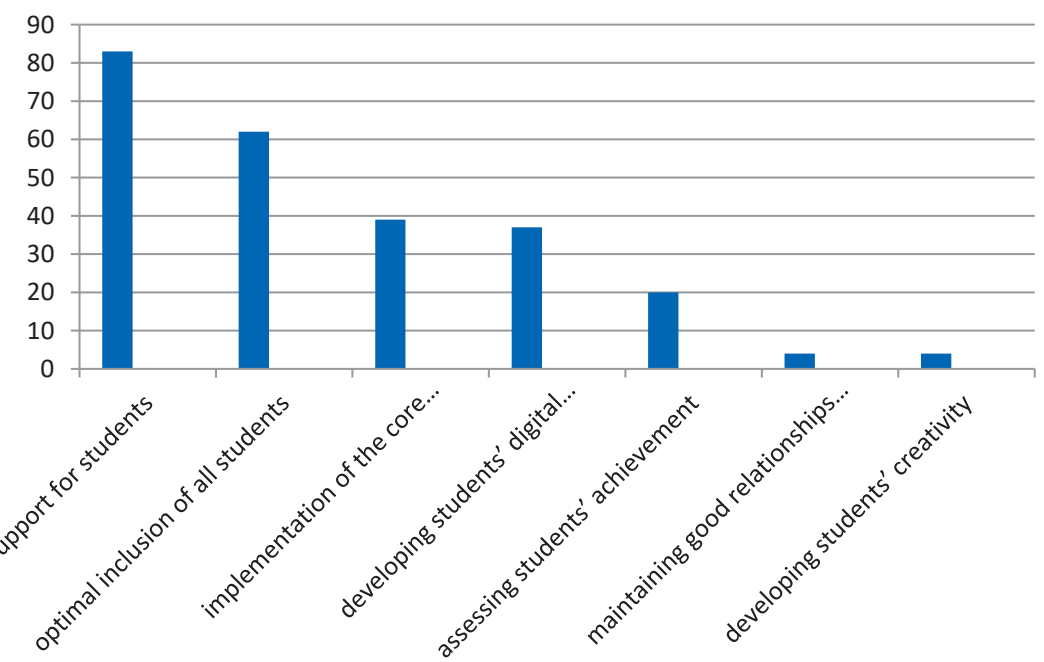

The above data clearly indicate that all respondents (83 people) checked the box "providing emotional support for students." It turned out that they appreciate the need to create a space in which their students feel safe. One of the respondents wrote: "Now, children especially need support, not educational instruction. The core curriculum is not going anywhere." In the context of potential (and already apparent) student problems, such an attitude deserves to be singled out.

Sixty-two teachers selected the option "optimal inclusion of all students," thinking about both children with various types of disabilities or developmental disorders and students who have experienced migration. Justifying their choice, one of the teachers wrote: "The teaching materials can often cause extra stress for the children of foreigners. That is why it is so important to include them in online lessons." How the respondents understand and provide this inclusion is discussed later in the article.

For almost half of the respondents (39 people), an important task is to "implement the core curriculum." These choices may testify to a sense of responsibility for providing students with knowledge that should be acquired at a given stage of education; they can also be derivative of a wider decision-making process proceeding from the regulations of the education authorities.

A slightly smaller number of people (37) decided that "shaping digital competences" was an important task. It seems that this task may be directly related to the methods of teaching/learning in isolation, the use of various educational platforms 
and materials (e.g. Moodle or e-textbooks), or distance and online learning applications (e.g. Microsoft Teams or Zoom).

Considerably fewer people, although still quite a few (20) indicated "assessing student progress." It can be assumed that grading should not be given priority at this time, in order to protect children's mental wellbeing, but also because of the unreliability and poor diagnostic capacity of the available tools.

Grading was last on the list of the tasks that I proposed. The respondents who selected the "other" option also indicated "developing students' creativity" and "maintaining correct and authentic contacts with parents" ( 4 people each). I believe that these tasks can be seen as attempts to make the best of the situation and to focus on particularly important issues: shaping one of the key competences and carrying out the idea of the actual tripartite education: student-teacher-home.

Apart from selecting (listing) the teacher's tasks, the respondents were also asked to make a hierarchy of their choices. Their answers are presented in Table 1.

Table 1. The Importance of the Tasks of Early Childhood Education Practitioners, as Selected by the Respondents

\begin{tabular}{|c|c|c|c|}
\hline Task & First place & Second place & Third place \\
\hline & Times selected & Times selected & Times selected \\
\hline Emotional support for students & 72 & 11 & 0 \\
\hline Optimal inclusion of all students & 16 & 42 & 4 \\
\hline Implementation of the core curriculum & 0 & 3 & 36 \\
\hline Developing students' digital competences & 0 & 7 & 30 \\
\hline Assessing student' progress & 0 & 0 & 20 \\
\hline Keeping in touch with parents & 4 & 0 & 0 \\
\hline Shaping students' creativity & 0 & 0 & 4 \\
\hline
\end{tabular}

The data in Table 1 confirm the choices illustrated in Figure 4: for teachers, providing "emotional support for students" is the number one task.

On the other hand, the analysis of the collected data led to the following conclusions: inclusion was not selected by 21 teachers at all, so the respondents did not consider this task important; among those who added inclusion to their list, 16 people considered it to be the most important task of the teacher, while 42 respondents put it in second place (after emotional support for students and maintaining contact with parents) and 4 respondents ranked it third. As I mentioned earlier, the respondents understood inclusion as it was defined by Wiszejko-Wierzbicka above. 


\section{Methods of Including Students with Migration Experience in Remote Education: Declarations of the Teachers Surveyed}

The analysis of the answers to subsequent questions about ways of including children who have experienced migration in the remote learning process led to a reflection that the answers presented in the previous section should be treated as general opinions from the category of "the way it should be," whereas the statements which I present below are declarations about the actual work of the respondents, so they belong to the category of "the way it is." This is evidenced, first of all, by the wide distribution of selected answers, as illustrated by the data in Figure 5 .

Figure 5. Including Students with Experience o Migration in Remote Education

\section{Inclusion in Distance Education}

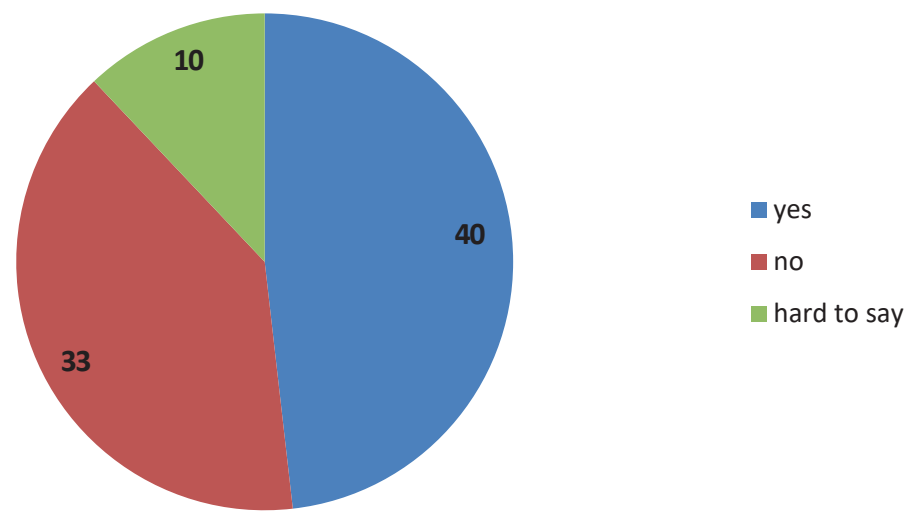

Comparing the number of teachers who use special methods for including students who have experienced migration in the current education process ( 40 people) with the number of respondents describing this task as important (62), it can be concluded that the awareness of its importance does not translate into everyday practice for everyone.

Why, then, do the surveyed teachers not use any ancillary methods of inclusion or treat such students as students with special educational needs? It is difficult to make any generalizations of value, since as many as 26 respondents (out of 33 "no" answers) did not justify their choice. On the other hand, those who chose to provide their reasons and arguments made the following statements: 
"For me, teaching without emotion, without expression is pointless!"

"We can remotely manage machines, money, property—but feelings? (maybe for a while) but not feelings. What about more in-depth questions: how? why? Can we treat them differently? love?, hate? e.t.c"

"I don't have this option, I work remotely by posting materials on the website."

"I've never thought about that."

The first three statements seem to express an opinion on the possibilities of online teaching/learning in general, while the fourth opinion indicates that the respondent is not aware of the need for special treatment of students with migration experience. However, it is impossible (in light of the collected material) to justify the reasons for this unawareness.

There were also two statements which excluded the consideration of special educational needs: "I don't have any such students in my class at the moment."

In the group of teachers who acknowledged that they use special methods for including students with migration experience in remote education, it is much easier to name and present these methods, as almost all respondents specified their answers in detail. Their distribution is illustrated in Table 2.

Table 2. Methods of Including Students with Experience of Migration in Remote Education: Declarations of the Teachers Surveyed

\begin{tabular}{|c|c|}
\hline Method & Number of Times Selected \\
\hline Setting additional tasks & 17 \\
\hline More frequent contact & 8 \\
\hline Additional online calls & 6 \\
\hline More frequent contact with the parents & 5 \\
\hline No answer & 4 \\
\hline
\end{tabular}

When describing the categorized methods, the teachers wrote:

"I'm trying to chat online with two children. I send them homework to do. I have two children from Ukraine and one from Vietnam. Unfortunately, due to poor knowledge of the Polish language, the girl from Vietnam did not take part in the chat."

"In my case, my parents cooperate well and I have no major problems with reaching five students of Ukrainian origin. I don't see any obstacles because we had already developed methods for cooperating and adapting the requirements to the abilities of a given student, especially their level of Polish."

"I think that in my case the involvement of the parents of Ukrainian students is a big advantage. The students are acquiring language skills and speaking Polish better 
and better. Previously, we communicated with one of the students in either English or Russian. Now I can talk easily in Polish. This is the result of the student's own work and their parents' support."

"During online lessons, I try to move slowly and translate all the new concepts. I translate and make corrections in written essays. I spoke to the parents of these children, they gave me their phone number and asked me to contact them in case of any difficulties. I also ask how they are doing from time to time."

These statements are a reminder of the premises that should be taken into account when creating the process of including children who have experienced migration in education (regardless of whether it takes place offline or online): the most important things are the awareness of the relationship between the effectiveness of teaching/ learning and the level of linguistic and cultural competences of the student, harmonious cooperation with the family, and effective personalization of instruction.

\section{Conclusion}

Being fully aware that they refer only to the material collected, I can draw the following conclusions:

Early school education teachers, in charge of culturally diverse classrooms, currently rely mainly on the methods developed in the course of earlier teaching practice.

- They make sure to support the linguistic and cultural competences of students who have experienced migration, in line with the principles of multicultural and intercultural education.

- They use various forms of personalization of the pace of instruction, in terms of both constructing knowledge and supporting skills.

- Remote teaching/learning is not conducive to (and sometimes even makes impossible) bolstering soft skills, mainly those related to establishing and maintaining interpersonal relationships.

When describing the most vital tasks of early childhood education teachers during the pandemic, the respondents indicated the need to provide emotional support to all students, not only those with migration experience.

To sum up, I would also like to emphasize that my understanding of inclusive education is consistent with the view of Iwona Chrzanowska and Grzegorz Szumski, who see it as "a continual process of education reform towards the harmonious, sustainable development of all students" (Chrzanowska, Szumski 2019: 12). Although contemporary Polish education is subject to a series of (pseudo)reforms, such a continual process should be part of everyday life, even in times of a pandemic. 


\section{Bibliography}

Chrzanowska I., Szumski G. (2019). Introduction, [in:] I. Chrzanowska, G. Szumski (eds.), Edukacja wtaczajaca w przedszkolu i szkole [Inclusive education in kindergarten and school], Warsaw: Foundation for the Development of the Educational System, Scientific Series, vol. 7 pp. 9-13.

European Commission. (2008). Green paper-Migration \& mobility: Challenges and opportunities for EU education systems, Brussels, 03.07.2008. COM (2008) 423 final. (https://eur-lex.europa.eu/legal-content/EN/ALL/?uri=CELEX\%3A52008DC0423 (accessed: 30.04.2020)

Regulation of the Minister of National Education of August 9, 2017 on the Rules for the Organization and Provision of Psychological and Pedagogical Assistance in Public Kindergartens, Schools, and Institutions, Journal of Laws 2017, item 1591.

Regulation of the Minister of National Education of Wednesday, March 11, 2020 - Ordinance on the Temporary Limitation of the Functioning of Educational System Facilities, Journal of Laws 2020, item 410. http://dziennikustaw.gov.pl/D2020000041001. pdf (accessed: 01.05.2020)

Regulation of the Minister of National Education of March 20, 2020 on the Temporary Limitation of the Functioning of Education System Facilities in Connection with the Prevention, Counteraction, and Combating of COVID-19, Journal of Laws 2020, item 492. https://www.gov.pl/web/edukacja/ksztalcenie-na-odleglosc-nowe-regulacje-prawne (accessed: 01.05.2020)

Regulation of the Minister of National Education of March 20, 2020 on Special Solutions in the Period of Temporary Limitation of the Functioning of Education System Facilities in Connection with the Prevention, Counteraction, and Combating of COVID-19, Journal of Laws 2020, item 493. https://www.gov.pl/web/edukacja/ ksztalcenie-na-odleglosc--nowe-regulacje-prawne (accessed: 01.05.2020)

Wiszejko-Wierzbicka D. (2012). Specjalne potrzeby ucznia czy szkoty? Przewodnik po edukacji wtaczajacej pomoca $w$ rozwijaniu ksztatcenia i uczestnictwa $w$ życiu szkoty [Special needs of the student or of the school? A guide to inclusive education to help develop teaching and participation in school life], "Niepełnosprawność - zagadnienia, problemy, rozwiązania,” no. 3 (4), pp. 71-86.

\section{Internet sources}

https://www.gov.pl/web/edukacja/wsparcie-uczniow-ze-specjalnymi-potrzebami-edukacyjnymi (accessed: 04.05.2020)

\section{ADDRESS FOR CORRESPONDENCE}

Ewa $\dot{Z}$ mijewska

Pedagogical University of Krakow e-mail: ewa.zmijewska@up.krakow.pl 